\title{
Earnings, Education and Training in China: The Migrant Worker Experience
}

George Messinis

Centre for Strategic Economic Studies, Victoria University

Enjiang Cheng

Victoria University and Zhejiang University

Working Paper No. 42

Centre for Strategic Economic Studies

Victoria University

Melbourne

January 2009

PO Box 14428

Melbourne VIC 8001 Australia

Telephone +61399191340

Fax +613 99191350

Contact : george.messinis@vu.edu.au 


\title{
Earnings, education and training in China: \\ The migrant worker experience*
}

\author{
George Messinis and Enjiang Cheng ${ }^{\dagger}$
}

Victoria University

Australia

\begin{abstract}
We utilise a new household survey to examine the impact of education and job training on labour income for migrant workers in China. Quantile regression is employed to account for selection bias. The evidence has as follows: (a) the returns to education and work experience are considerable but non-linear; (b) job training is valuable; (c) the Hukou system of residence is a severe constraint on gains to work experience; and (d) women earn more than men due to endowment effects. This evidence calls for new policy initiatives in China to raise the skills of migrant workers and abolish discriminatory policies.
\end{abstract}

Keywords: Education; Training; Earnings; Migration; China

JEL Classification: C5, I2, J2, J3, J4, O1, O2, P2

\footnotetext{
† Victoria University. Correspondence: George.Messinis@vu.edu.au Victoria University and Zhejiang University. Correspondence: Enjiang.Cheng@vu.edu.au

* The authors would like to thank CARD Centre of Zhejiang University for the organization of the survey in Hangzhou.
} 


\section{Introduction}

Swift economic reforms since 1978 have transformed China into the 'world's most successful economy' with an average of 8 percent per capita annual growth and unprecedented gains in average living standards. China's economic success has relied heavily on internal labour migration that has provided special economic zones and other coastal regions with abundant labour supply. ${ }^{1}$

China has also experienced a trend of growing income disparities. The ruralurban divide has been a key feature of the rise in income inequality in China (Ravallion and Chen 2007; Au and Henderson 2006; Sun 2004). Yet, evidence suggests that worker migration has helped China bridge the rural-urban income gap since it has allowed rural households to share in the economic gains (Wan 2004).

Labour economics has highlighted a positive relation between human capital and wages. In an attempt to make this relation work for rural households, China has introduced mandatory schooling in 1986 and nation-wide training programs for potential migrants in 2004. However, the public education and training system discriminates against migrant workers who live in urban areas since public expenditures are allocated on the basis of the Hukou system of permanent residence. ${ }^{2}$

The value of education for migrant workers in China has been examined in several studies and the overall evidence points to modest and diminishing returns to schooling. ${ }^{3}$ The role of on-the-job training, on the other hand, has been neglected according to Liu and Xiao (2006) who recommend that greater attention is paid to the diverse roles of education and training in China and other transition economies since the skills acquired during formal education under a planned economy may differ substantially from those required at the workplace in a market economy.

In view of China's policy emphasis on education, this study contributes to the literature in three ways. First, it utilises data from a new survey in China's Zhejiang Province that allows us to estimate the value of education for migrant workers in China. Second, the study pays attention to new skills acquired at the workplace. This seems appropriate for developing countries where new evidence suggests that skills

\footnotetext{
${ }^{1}$ See details in Sachs (2005).

${ }^{2}$ Hukou is a Chinese term referring to the Household registration system.

${ }^{3}$ For example, de Brauw and Giles (2006) and Zeng (2004).
} 
matter more than formal education. ${ }^{4}$ The new survey allows us to examine the role of time spent on job training as an independent factor. The focus on job training is important in view of new insights in labour economics. Two new theories have challenged the traditional view of job training that sees training as a substitute for education. One is search and matching theory that perceives job training to be complementary to formal education; namely, it bridges the gap between generic skills and job-specific skills. ${ }^{5}$ Another is the human capital depreciation theory that highlights skill obsolescence as a result of wear, atrophy and technological change. ${ }^{6}$ The international literature suggests that job training is valuable to workers, especially the low-skilled. ${ }^{7}$ Theory also suggests that firm behaviour can potentially produce sub-optimal levels of employer-based job training (Acemoglu and Pischke 1999). The temporary residence status of migrant workers in China may exacerbate this problem.

A third contribution to the literature is to apply recent econometric techniques to addresses the potential problem of non-random selection bias in worker participation in internal migration as well as and firm selection of relatively more able workers in job training is subject to selection bias. We employ quantile regressions to control for selection bias.

The paper is organised as follows. Section two summarises the literature on which this paper draws. Section three outlines our empirical methodology. Section four presents the empirical results. Finally, section five concludes with a discussion on the implications of the new evidence for China's policy on domestic migrant workers.

\section{Background}

China is characterised by a dual economy by which the vast rural population has considerably lower levels of incomes and considerably less access to key social

\footnotetext{
${ }^{4}$ See Hanushek and Wößmann (2007).

${ }_{6}^{5}$ For more details, see Linsley (2005) and van Smoorenburg and van der Velden (2000).

${ }^{6}$ Mincer and Ofek (1982), Baldwin and Johnson (1995) and de Grip (2004) are key studies that attempt to model skill obsolescence and account for job training.

${ }^{7}$ Van Smoorenburg and van der Velden (2000), de Grip and van Loo (2002) and Arulampalam et al. (2004) find evidence of substantial returns to training.
} 
services, namely education, medical and insurance services and social welfare. ${ }^{8}$ Most striking is the fact that 75 per cent of the 85 million illiterates and semi-illiterates in China were concentrated in the Western rural areas of the country (Communist Party's School 2005).

Sharp spatial disparities are also discernible in education. In rural China, education up to middle school (eight to nine years of education) became mandatory only in 1986 with the Law on Compulsory Education (Tsang 1996). According to a survey conducted by the Communist Party's School (2005) in the 16 provinces of China, the average years of education received by the rural population in China was below 7 years, almost three years lower than their urban counterparts. Likewise, less than one per cent of all labourers between the age of 15 and 64 in rural China received tertiary education, 13 per cent lower than their urban counterparts. Moreover, despite mandatory schooling to year nine (6 years of the primary school education and three years of middle school education), less than 30 per cent of the rural children at the school age were able to finish their nine years of education. It was also found that increases in school fees, poverty and poor educational quality in rural areas were major contributors to the low levels of education achieved in rural China.

China's dual economy has also experienced a remarkable surge in domestic migration by workers who leave rural communities to seek jobs in big cities. Initially conceived as a solution to severe shortages of labour in fast-growth urban regions, migrant workers were granted special rights of temporary residence in the early 1990s. Since, worker migration has grown immensely (Sachs 2005). According to a Chinese Government report (The Research Group on China's Farmer Turn Workers 2006), the number of migrant workers increased from 30 million in 1989 to 62 million by 1993 . In 2004, the number of migrant workers reached 118 million, or 23.8 per cent of the total rural labour force in China.

On the assumption that China's growth is sustainable, worker migration emerges as a major policy instrument via which rural China can catch up with the living standards enjoyed by much of the urban population. There is growing evidence of this potential. China's Ministry of Agriculture estimated that there were around 98 million of domestic migrant workers in 2003 and their remittance reached 370 billion RMB

\footnotetext{
${ }^{8}$ For a detailed description of unequal access to social services, see Tong (2006).
} 
(44.7 Billion US\$), that constitutes 40 per cent of total rural household income in China (Ministry of Agriculture 2004). Du et al. (2005) report that migrant workers increase a household's per capita income by 8.5 to 13.1 percent. Also, the wages of migrant workers have been significantly higher than those earned by agricultural workers. Wan (2004) found that the average wage of migrant workers in the Henan Province reached 4,717 Rmb in 2003, 82.4\% higher than the average net income of agricultural workers in the province. ${ }^{9}$

With the world economy relying heavily on low wages, it is no wonder that public policy in China has focused on domestic migration as the principal source of low-cost labour (Zheng 2004; Chen 2004) and there has been little attention to education and skill development for migrant workers in China. Economic intuition highlights human capital as a 'crucial aspect in development' (Wößmann 2003) but little is known about the nature and drivers of human capital growth in developing nations. As major players in world economic development, domestic migrant workers offer researchers the opportunity to learn about the process of learning in the developing world since domestic migrants are part of the same national education system but have little prior knowledge of the jobs they fill. Moreover, migrants do not fit in well with established labour coalitions since they have a strong work ethic and often face hostile attitudes and discriminatory policies as temporary urban residents. ${ }^{10}$ These characteristics make it easier to disentangle the role of education from that of learning at the workplace.

The current state of knowledge of the human capital of migrants is limited to few basic indicators. One is that the average level of education of migrant workers in China is significantly higher than that of rural labourers but lower than their urban coworkers. Zhang et al (2004) estimate that of all the migrant workers, $10 \%$ are of high school graduates, $30 \%$ middle school graduates, $30 \%$ of primary school graduates and some are illiterate. Moreover, $80 \%$ of migrant workers have received no formal

\footnotetext{
${ }^{9}$ Note that migrant workers incur higher living expenses in urban areas. Thus, Wan (2004) overestimates the net income gap between migrant workers and agricultural workers.

${ }^{10}$ Some cities restrict the entry of migrant workers into certain industries. Relative to their urban peers, migrant workers face higher costs for further education, medical care and school fees for their children, and receive lower entitlements with respect to bonus income and retirement benefits. This discrimination stems from their status as temporary residents due to the Hukou system of registered permanent residence which is location specific (Zhang et al 2004; Whalley and Zhang 2004).
} 
training at all. Also, migrant workers tend to concentrate in unskilled employment (Fleicher and Wang 2004).

Private returns to education have improved over time as China shifted from a planned to a market economy (Li and Zhang 1998; Yang 2004). In a survey of 616 migrant workers in Chengdu City in 2000, Zeng (2004) found that the return of an extra year of education on income is positive but only small at 1 per cent. It was also found that women earned 10 per cent less than men. Also, the effect of the years working experience as a migrant worker is positive, at 0.5 per cent.

With respect to job training, migrant workers seem to be twice disadvantaged. First, employer-based training appears to be inadequate since there are a few incentives to job training given the temporary nature of employment for migrant workers (The Research Group on China's Farmer Turn Workers 2006). According to the research group, it was common for many employers not to provide even the basic occupational training to migrant workers as required by the state and the legal system in China. According to the data provided by the Ministry of Construction, of 32 million migrant workers employed in China's construction industry, only 10 per cent received some kind of training. Second, current state-funded training programs are of little benefit to migrant workers since funds are mainly targeted towards retrenched workers from state enterprises. Only since 2004, the central government has begun to allocate funds for potential migrants on the basis of the Hukou system of residence. Thus, if at all, migrant workers receive state-funded training prior to migration when there is little knowledge of the skills required in big cities. Further, migrants contribute to urban taxation but local governments have no obligation to subsidise training for migrant workers.

To our best knowledge, we can cite only two empirical studies that explore the link between job training and earnings in China. One is by Liu and Xiao (2006) who utilise a 1998 survey of 16,485 employees from 365 firms in six provinces. Although they do not control for selection bias, they find that participation in on-the-job training (i.e., a binary variable) has a positive but modest effect on wage growth. Zeng (2004) is the only study that examines the impact of training for migrant workers. He uses information on trade-specific skills to construct a measure of 'skill mastering' that enters a standard Mincerian equation (see next section) as a proxy for 'informal 
training'. He concludes that 'informal training' contributes to income by 2.8 per cent. However, it is impossible to know whether this measure is as a proxy for current onthe-job training or whether it is endogenous (i.e., higher income or higher education may enable individuals to invest in skills).

Given the surge in worker migration in recent times, the search for new insights on the value of education and training in China seems highly desirable. Below, we outline an empirical methodology and a new data set that enable us to obtain unbiased estimates of returns to both education and on-the-job training.

\section{Methodology and Data}

\section{Methodology}

Mincer's (1974) pioneer work has equipped economists with a powerful methodology that allows them to estimate the value of investment in education to individuals. The approach is summarised in the standard 'Mincerian' equation:

$$
L W_{i}=\beta S_{i}+\sum_{q=1}^{2} \gamma_{q} \mathrm{E}_{\mathrm{i}}^{\mathrm{q}}+\mathrm{X}_{\mathrm{i}} \delta+\varepsilon_{i}
$$

Here, $L W_{i}$ is the $\log$ of earnings for worker $i, S_{i}$ is her actual years of education, $\beta$ is the rate of return to one year of education, $E_{i}$ is potential work experience in a second-order polynomial, $\mathrm{X}_{\mathrm{i}}$ is a vector of other explanatory variables such as gender, $\gamma$ and $\delta$ are coefficient vectors and $\varepsilon_{\mathrm{i}}$ is a random error term. Equation (1) has been widely applied to estimate returns to education in various countries. Empirical research points to several key findings: estimates of $\beta$ range from 0.05 to 0.15 ; women earn more than men; there are diminishing returns to education, and the payoff to education is higher for more disadvantaged individuals. ${ }^{11}$

\footnotetext{
${ }^{11}$ See Krueger and Lindahl (2001), Heckman et al. (2003) and Psacharopoulos and Patrinos (2004). On average, the OLS estimate is 0.066 while the 2SLS estimate is 0.093 (Krueger and Lindahl 2001).
} 
In recent times, the Mincer approach has been extended to accommodate new insights on the role of human capital. First, there is ample empirical evidence showing that the traditional measure of years of education is a poor indicator of education quality and that its effect on wages is non-linear. Second, in the spirit of Mincer (1962, 1989), Mincer and Ofek (1982) and Veum (1999), it seems intuitive that job training adds to the human capital stock. Third, it has been argued that the quadratic term in (1) does not fully capture the impact work experience has on earnings; a fourth degree polynomial has been proposed by Murphy and Welch (1990), Card (1999), Trostel (2005) and Lemieux (2006). Thus, we examine the following model:

$$
L W_{i}=\sum_{k=1}^{n} \beta_{k} S_{k, i}+\sum_{q=1}^{4} \gamma_{q} \mathrm{E}_{\mathrm{i}}^{q}+\mathrm{X}_{\mathrm{i}} \delta+\phi \mathrm{T}_{\mathrm{i}}+\varepsilon_{i}
$$

where $\mathrm{S}_{\mathrm{k}, \mathrm{i}}$ is for the $\mathrm{k}^{\text {th }}$ level of education, work experience is expressed as a quartic function and $\mathrm{T}_{\mathrm{i}}$ stands for time spent on job training.

Note, however, that we also deal with the possibility that participation in job training may be subject to selection bias. Kuruscu (2006) has shown that returns to training in the USA are smaller than previously thought when he accounts for such bias. Further, it is feasible that certain groups of workers may self select to become internal migrants. These two sources of non-random selection introduce a misspecification bias in OLS estimation. The empirical literature has dealt with this potential problem using three alternative strategies. First is Heckman's (1979) twostep or maximum likelihood approach that specifies explicitly a selection equation that describes employment participation. There are two major issues in this approach. One, it is difficult to identify variables that exclusively enter the selection equation and have no impact on wages. Also, maximum likelihood relies on the dubious assumption of a bivariate normal distribution. ${ }^{12}$

The second approach exploits the notion that participation in employment and the returns to education are both driven by the unobservable latent factor of ability. In order to control for this omitted variable, this approach utilises quantile regressions. ${ }^{13}$

\footnotetext{
${ }^{12}$ For a comprehensive survey, see Vella (1998).

${ }^{13}$ See for example Buchinsky (1994) and Angrist, Chernozhukov and Fernandez-Val (2006).
} 
The idea is that by restricting the analysis to a particular quantile, the omitted variable bias is minimised since ability is likely to be homogeneous within a quantile band. Thus, rather than searching for an explicit structural relation for the participationability-education nexus, this approach reduces the problem to one of a wage equation for each quantile. Following Buchinsky (1994), the quantile regression (QR) model can be expressed as follows:

$\ln W_{i}=Q_{\theta}\left(\ln W_{i} \mid x_{i}\right)+u_{\theta i}=x_{i} \beta_{i}+u_{\theta i}$

where $\mathrm{Q}_{\theta}(\bullet)$ is the conditional quantile of $\ln \mathrm{W}_{\mathrm{i}}$ (i.e., conditional on a vector of covariates, $\left.\mathrm{x}_{\mathrm{i}}\right)$ for quantile $\theta$ where $\theta \epsilon(0,1)$. Assuming integrability, the linear $\mathrm{QR}$ vector solves the minimisation problem:

$$
\beta(\theta):=\arg \min _{\beta \in R^{d}} E Q_{\theta}\left[\rho_{\theta}\left(\ln W_{i}-x_{i} \beta_{i}\right)\right]
$$

where $\rho_{\theta}=(\theta-1(\varepsilon \leq 0)) \varepsilon$ and $d$ is the dimension of the explanatory variable vector, $x_{i}$.

A third alternative is the copula approach that relaxes the assumption of normally distributed marginal distributions and offers a variety of possible non-Gaussian joint distributions. This approach has been used widely in finance but recently it has been applied to sample selection problems. ${ }^{14}$ Yet, this approach has its own limitations for it is not trivial to select the appropriate copula, given the vast amount of possible solutions and uncertainty about the marginal distributions (Michiels and De Schepper 2007; Trivedi and Zimmer 2005). Hence, we follow Angrist, Chernozhukov and Fernandez-Val (2006) and adopt the QR approach.

\section{Data}

The data for this article are taken from a new 2005 survey of 400 migrant workers in Hangzhou of Zhejiang Province. The Chinese census defines migrant workers as rural labourers transferred out of their home county for more than six months. Most

${ }^{14}$ Smith (2003) and Genius and Strazzera (2008) apply bivariate copulas. For a more comprehensive survey, see Trivedi and Zimmer (2005). 
inter-provincial migrant workers originate from the Central and Western provinces and are employed in the coastal provinces.

Zhejiang was selected as a province with a high concentration of migrant workers. Given the rapid development of private enterprises and foreign investment in the province, Zhejiang is one of the primary destinations for migrant workers in China. The survey of migrant workers in Hangzhou of Zhejiang Province was conducted in December 2004 and January 2005. A total of 400 migrant workers were randomly selected for the survey, although consideration was given for the survey to cover migrant workers across a wide range of industries. Of the 400 people surveyed for this study, 87 percent were Han Chinese. The remaining 13 percent of people identified as Miao, Tujia, Mongol, and other ethnic groups. Migrant workers in the study represent a younger and more highly educated work force from rural China, especially from lower-income areas of China. Nearly 95 percent of the migrant workers here are literate, although 10 percent have less than four years of formal education and have difficulty reading and writing while 30 percent have not completed middle school (i.e., 9 years of education). Women migrant workers, representing 28 percent of the sample, have slightly lower levels of education. Of those surveyed, 70 percent were married, and 60 percent chose to leave their children back at their place of origin.

The interviews were conducted by agricultural economics undergraduate students at Zhejiang University, supervised by a staff member of the university. The survey contains information on basic wages, bonus income, remittances, years of education completed, work experience as a migrant worker, tenure with the current employer, time spent in job training provided by one's employer, industry sector, occupation and skill, consumption expenditures and personal characteristics. With respect to training, participants were asked the following question: "At your current working unit, have you received training? If yes, how many days of formal training received?" We utilise information on the latter to estimate returns to training. ${ }^{15}$

However, there is a concern with the measurement of wages. Survey participants were requested to report their monthly basic wage in their current job. We convert this

\footnotetext{
${ }^{15}$ These data relate to the total time of training received from the current employer. Thus, we have adjusted for tenure and converted the original data into weeks per year by adjusting by a factor of $1 /\left(\mathrm{TEN}^{*} 4\right)$ where TEN is months of employment with the current employer.
} 
to weekly wages and add the weekly rate of bonuses to obtain the first, 'incomebased', estimate of wages, $\mathrm{W}^{1}$. We expect that $\mathrm{W}^{1}$ will under-estimate earnings due to under-reporting or due to payments in kind such as free accommodation or free meals. These benefits will vary across industries and may be higher for women. Thus, we utilise an alternative 'expenditure-based' measure; that is, the sum of weekly total expenditure, the average weekly remittance sent home during 2003-2004, and imputed weekly rent if the worker states that 'the employer provide the migrant worker with the housing free of rent'. Note, however, that this second measure of wages, $\mathrm{W}^{2}$, does not include savings that workers keep in the city. Yet again, it is intuitive that such savings would most likely form part of savings sent home as remittances, a component of $\mathrm{W}^{2}$. Hence, we consider this to be a more accurate estimate of migrant worker earnings.

\section{Empirical Results}

In column 1 of Table 1 , we begin with summary statistics for our sample by occupation, industry and gender. It appears that $59.7 \%$ of migrants in the sample report to be unskilled as they have no trade. Also, the majority of migrants work in the manufacturing $(28.2 \%)$, services $(18.5 \%)$ and construction $(25.2 \%)$ sectors. This is consistent with previous studies in China. According to The Research Group on China's Farmer Turn Workers (2006), of all the migrant workers in China, 30.3\% were employed in the manufacturing industry, $22.9 \%$ in the construction industry and $10.4 \%$ in the service sector. Also, a study of non government employees in Guangzhou, the capital of Guangdong Province, reports that about 55\% of the labour force in the city was employed in the manufacturing industry, $10 \%$ in construction, $25 \%$ in the service sector, and 6\% in transportation (Guangdong Enterprises Survey Team, 2006). In general, migrant workers have been employed in the more marketoriented industries where there is high demand for unskilled labour (Sun et al. 2005). 
Table 1. Education, Experience and Training: Migrant Workers, China 2005

\begin{tabular}{|c|c|c|c|c|c|c|}
\hline Group & 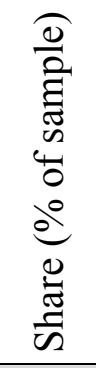 & 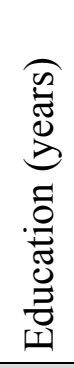 & 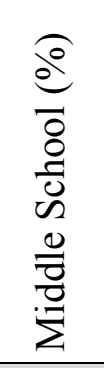 & 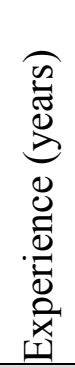 & 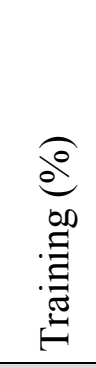 & 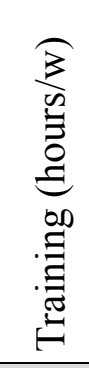 \\
\hline \multicolumn{7}{|l|}{ Occupation } \\
\hline Unskilled & 59.7 & 6.9 & 34.7 & 3.6 & 30.9 & 4.6 \\
\hline Drivers & 6.2 & 7.6 & 44.0 & 5.4 & 56.0 & 8.3 \\
\hline Cooks & 7.0 & 6.7 & 35.7 & 3.2 & 14.3 & 7.5 \\
\hline Barbers & 1.2 & 8.0 & 60.0 & 2.2 & 40.0 & 32.6 \\
\hline Tailors & 1.2 & 7.2 & 40.0 & 3.0 & 40.0 & 3.5 \\
\hline Mechanics & 9.7 & 8.5 & 53.8 & 3.9 & 41.0 & 11.6 \\
\hline Builders & 5.2 & 8.3 & 52.4 & 3.9 & 23.8 & 1.6 \\
\hline Carpenters & 3.0 & 8.7 & 58.3 & 4.9 & 8.3 & 1.7 \\
\hline Foremen & 1.7 & 8.4 & 71.4 & 4.8 & 14.3 & 0.4 \\
\hline Managers & 2.0 & 6.9 & 50.0 & 5.7 & 25.0 & 1.2 \\
\hline Skilled-Other & 2.7 & 8.7 & 81.8 & 4.2 & 45.4 & 2.1 \\
\hline \multicolumn{7}{|l|}{ Industry } \\
\hline Transport & 8.3 & 6.6 & 30.3 & 5.8 & 45.4 & 5.6 \\
\hline Construction & 18.5 & 6.6 & 24.3 & 4.1 & 10.8 & 2.0 \\
\hline Manufacturing & 28.2 & 7.7 & 53.1 & 3.7 & 31.0 & 3.7 \\
\hline Services & 25.2 & 7.0 & 35.6 & 3.1 & 27.7 & 5.7 \\
\hline Other & 19.7 & 8.1 & 53.2 & 3.6 & 50.6 & 11.3 \\
\hline \multicolumn{7}{|l|}{ Gender } \\
\hline Men & 72.0 & 7.7 & 46.5 & 4.1 & 29.5 & 4.8 \\
\hline Women & 28.0 & 6.3 & 28.6 & 3.0 & 36.6 & 7.5 \\
\hline All workers & & 7.3 & 41.5 & 3.8 & 31.5 & 5.6 \\
\hline
\end{tabular}

Note: Percentages may not sum up to 100 due to rounding. The 'unskilled' group comprises of workers who did not report an occupation and excludes workers in military service. Column three is the share of workers who have completed middle or higher level of school. Training time in this table is measured in average hours per week. 
Columns 2-3 of Table 1 summary average years of education and the share of migrant workers who completed middle school or higher. As expected, skilled workers ${ }^{16}$ exhibit higher levels of education. Cooks, managers, construction and transport workers, and women have experienced below average levels of education. These differences are starker with respect to the completion of the middle school where the attainment rates for barbers, foremen, unspecified skilled workers, and men are $60 \%, 71.4 \%, 81.8 \%$, and $46.5 \%$ respectively. In contrast, only $35.7 \%$ of cooks, $24.3 \%$ of construction workers and $28.6 \%$ of women have completed middle school. Column 4 of Table 1 reports the years of experience as migrant workers. The overall average is about four years with a minimum value of 2.2 years for barbers and a maximum of 5.8 years for transport workers. In columns 5-6 of Table 1 there are summary statistics for job training. Here, $31.5 \%$ of all migrant workers, $36.6 \%$ of women and only $29.5 \%$ of men have undergone training. These results contrast sharply with the finding in Liu and Xiao (2006) that $64 \%$ of all workers received onthe-job training during 1993-1998. They also confirm the suspicion that employers will be more reluctant to provide training to migrant workers than to other workers. The incidence of training, however, varies substantially across occupation with only $14.3 \%$ of cooks, $8.3 \%$ of carpenters and $14.3 \%$ of foremen having participated in training. In contrast, drivers, barbers, mechanics, and workers in the service sector have experienced strong participation in training. The last three groups, in particular, have dedicated considerable time in training that can be attributed to apprenticeships.

Next, column 1 in Table 2 presents the results from OLS robust estimation of (2) when the 'income-based' wages measure, $\mathrm{W}^{1}$, is used as the explained variable. The results suggest that education does not contribute to wages at any level. Only the linear term of experience is significant, employment in the services sector is associated with a $12.5 \%$ wage penalty, and females seem to earn $12.2 \%$ less than men. The latter finding seems consistent with previous studies in China (Wu 2001, p.100).

\footnotetext{
${ }^{16}$ The 'unskilled' group includes workers who did not report having an occupation or a trade; services sector workers are treated as 'unskilled'.
} 
Table 2. Education, training and reported wages:

Migrant workers, China 2005

\begin{tabular}{|c|c|c|c|c|c|c|}
\hline & $\begin{array}{l}\text { (1) } \\
\text { All }\end{array}$ & $\begin{array}{l}(2) \\
\text { Q10 }\end{array}$ & $\begin{array}{c}(3) \\
\text { Q25 }\end{array}$ & $\begin{array}{c}(4) \\
\text { Q50 }\end{array}$ & $\begin{array}{c}(5) \\
\text { Q75 }\end{array}$ & $\begin{array}{c}(6) \\
\text { Q90 }\end{array}$ \\
\hline Constant & $\begin{array}{l}5.270^{* * *} \\
(0.093)\end{array}$ & $\begin{array}{l}4.946^{* * *} \\
(0.212)\end{array}$ & $\begin{array}{l}5.058^{* * *} \\
(0.084)\end{array}$ & $\begin{array}{l}5.372^{* * *} \\
(0.077)\end{array}$ & $\begin{array}{l}5.458^{* * *} \\
(0.137)\end{array}$ & $\begin{array}{l}5.684 * * * \\
(0.271)\end{array}$ \\
\hline Education: Years 6-8 & $\begin{array}{c}0.049 \\
(0.056)\end{array}$ & $\begin{array}{c}0.009 \\
(0.122)\end{array}$ & $\begin{array}{l}0.014 \\
(0.046)\end{array}$ & $\begin{array}{c}0.011 \\
(0.042)\end{array}$ & $\begin{array}{c}0.061 \\
(0.070)\end{array}$ & $\begin{array}{l}-0.009 \\
(0.133)\end{array}$ \\
\hline Education: Year 9+ & $\begin{array}{c}0.044 \\
(0.054)\end{array}$ & $\begin{array}{c}0.042 \\
(0.113)\end{array}$ & $\begin{array}{l}0.009 \\
(0.046)\end{array}$ & $\begin{array}{l}0.020 \\
(0.042)\end{array}$ & $\begin{array}{c}0.077 \\
(0.072)\end{array}$ & $\begin{array}{l}-0.038 \\
(0.138)\end{array}$ \\
\hline Experience & $\begin{array}{c}0.132^{*} \\
(0.064)\end{array}$ & $\begin{array}{l}0.024 \\
(0.131)\end{array}$ & $\begin{array}{l}0.097 * \\
(0.054)\end{array}$ & $\begin{array}{c}0.019 \\
(0.047)\end{array}$ & $\begin{array}{c}0.072 \\
(0.080)\end{array}$ & $\begin{array}{l}0.306^{* *} \\
(0.134)\end{array}$ \\
\hline Experience $^{2} / 10$ & $\begin{array}{l}-0.177 \\
(0.166)\end{array}$ & $\begin{array}{c}0.010 \\
(0.328)\end{array}$ & $\begin{array}{l}-0.152 \\
(0.137)\end{array}$ & $\begin{array}{l}-0.003 \\
(0.114)\end{array}$ & $\begin{array}{l}-0.074 \\
(0.196)\end{array}$ & $\begin{array}{l}-0.739 * * \\
(0.327)\end{array}$ \\
\hline Experience $^{3} / 100$ & $\begin{array}{l}0.099 \\
(0.147)\end{array}$ & $\begin{array}{l}-0.048 \\
(0.272)\end{array}$ & $\begin{array}{c}0.074 \\
(0.119)\end{array}$ & $\begin{array}{l}-0.015 \\
(0.097)\end{array}$ & $\begin{array}{c}0.006 \\
(0.167)\end{array}$ & $\begin{array}{l}0.653 * * \\
(0.281)\end{array}$ \\
\hline Experience $^{4} / 100$ & $\begin{array}{l}-0.002 \\
(0.004)\end{array}$ & $\begin{array}{l}0.002 \\
(0.007)\end{array}$ & $\begin{array}{l}-0.001 \\
(0.003)\end{array}$ & $\begin{array}{c}0.001 \\
(0.002)\end{array}$ & $\begin{array}{l}0.001 \\
(0.004)\end{array}$ & $\begin{array}{l}-0.017 * * \\
(0.007)\end{array}$ \\
\hline Manufacturing & $\begin{array}{l}-0.006 \\
(0.037)\end{array}$ & $\begin{array}{c}0.096 \\
(0.105)\end{array}$ & $\begin{array}{l}0.161 * * * \\
(0.042)\end{array}$ & $\begin{array}{l}0.100^{* * *} \\
(0.038)\end{array}$ & $\begin{array}{l}-0.062 \\
(0.065)\end{array}$ & $\begin{array}{l}-0.206 \\
(0.127)\end{array}$ \\
\hline Services & $\begin{array}{l}-0.125^{* *} \\
(0.057)\end{array}$ & $\begin{array}{l}-0.011 \\
(0.120)\end{array}$ & $\begin{array}{c}0.019 \\
(0.049)\end{array}$ & $\begin{array}{l}-0.044 \\
(0.043)\end{array}$ & $\begin{array}{l}-0.162^{* *} \\
(0.073)\end{array}$ & $\begin{array}{l}-0.341^{* *} \\
(0.145)\end{array}$ \\
\hline Tenure & $\begin{array}{c}0.023 \\
(0.017)\end{array}$ & $\begin{array}{l}0.020 \\
(0.020)\end{array}$ & $\begin{array}{l}0.023^{* *} \\
(0.011)\end{array}$ & $\begin{array}{l}0.045^{* * *} \\
(0.009)\end{array}$ & $\begin{array}{l}0.060^{* * *} \\
(0.014)\end{array}$ & $\begin{array}{l}0.062^{* *} \\
(0.031)\end{array}$ \\
\hline Children & $\begin{array}{l}-0.060 \\
(0.062)\end{array}$ & $\begin{array}{c}0.034 \\
(0.121)\end{array}$ & $\begin{array}{l}-0.008 \\
(0.044)\end{array}$ & $\begin{array}{l}-0.063^{*} \\
(0.038)\end{array}$ & $\begin{array}{l}-0.068 \\
(0.065)\end{array}$ & $\begin{array}{l}-0.176 \\
(0.135)\end{array}$ \\
\hline Female & $\begin{array}{l}-0.122^{*} \\
(0.066)\end{array}$ & $\begin{array}{l}-0.190^{*} \\
(0.113)\end{array}$ & $\begin{array}{l}-0.202^{* * *} \\
(0.045)\end{array}$ & $\begin{array}{l}-0.217^{* * *} \\
(0.039)\end{array}$ & $\begin{array}{l}-0.158^{* *} \\
(0.069)\end{array}$ & $\begin{array}{l}-0.035 \\
(0.145)\end{array}$ \\
\hline Training Time & $\begin{array}{c}0.014 \\
(0.012)\end{array}$ & $\begin{array}{c}0.016 \\
(0.016)\end{array}$ & $\begin{array}{c}0.010 \\
(0.007)\end{array}$ & $\begin{array}{c}0.012 * \\
(0.006)\end{array}$ & $\begin{array}{c}0.002 \\
(0.012)\end{array}$ & $\begin{array}{c}0.002 \\
(0.021)\end{array}$ \\
\hline Observations & 383 & 383 & 383 & 383 & 383 & 383 \\
\hline $\mathrm{R}^{2}$ & 0.16 & 0.06 & 0.10 & 0.13 & 0.15 & 0.14 \\
\hline
\end{tabular}

In an attempt to minimise the potential bias of non-random sample selection, we proceed with quantile regressions, as in Angrist, Chernozhukov and Fernandez-Val (2006). Columns 2-6 in Tables 2 report quantile regression outcomes for $\theta=0.1,0.25$, $0.5,0.75$, and 0.9 . These results are very similar to those obtained in OLS estimation in column 1. However, workers in manufacturing and with higher tenure earn more 
than others. The former may be due to a strong demand for unskilled labour while the latter is consistent with previous evidence (Cardoso 2005). ${ }^{17}$

In Table 3, we have repeated the exercise of OLS and quantile regressions except that now we use the 'expenditure-based' measure of wages, $\mathrm{W}^{2}$, as the dependent variable. In contrast to results in Table 2, the OLS estimates in column 1 suggest that education is indeed beneficial at the labour market for migrant workers. Completion of lower-middle school adds $12.1 \%$ to earnings while completion of middle school or higher yields a return of $10.3 \%$. This suggests that attainment of higher education is not more valuable than attainment of lower middle school; a finding that is consistent with existing literature cited earlier.

Work experience as migrant worker is also important but now all the quartic terms are statistically significant. ${ }^{18}$ Although employment in manufacturing does not appear to impact on earnings, working in the services sector does attract a wage penalty. This may be due to an oversupply of workers in this sector or due to a wage discrimination against migrant workers in the public sector. On the other hand, the presence of children in the family and females associate with a wage premium. The former is plausibly due to motivation and family support in household production. We explore the drivers of the latter below. Column 1 in Table 3 also shows that job training provided by the employer has significant benefits. In particular, a week of job training adds $4.6 \%$ to earnings.

Columns 2-6 in Table 3 report quantile regression estimation results. These are qualitatively similar to those in column 1 except that the returns to education and experience are higher for those in the bottom $10 \%$ of the distribution (i.e., the least able workers). It is, however, worth emphasising that all but the top $10 \%$ of workers benefit form education and experience. Moreover, the returns to training are almost identical for all groups below the top quantile and very close to the $4.6 \%$ estimate

\footnotetext{
${ }^{17}$ We also experimented with an expanded set of covariates that included indicator variables for marriage and for being of schooling age during the Cultural Revolution. The latter is as in Meng and Gregory (2007) who find that workers who were pupils in urban China during the period 1966-1977 have experienced a wage penalty. These two variables were used in all regression in this study but none were significant. The evidence on marriage is in line with $\mathrm{Wu}$ (2001) and Zhang and $\mathrm{Si}$ (2006) while that on 'interrupted education' is consistent with Meng and Gregory (2007). Estimates are available from the authors.

${ }^{18}$ Note that we used potential work experience (i.e., age-education-6) as an alternative proxy for work experience but none of the coefficients were statistically significant.
} 
observed in column 1 of Table 3 . This suggests that there is little sample selection bias in the OLS estimate, in contrast to Xiao and Tsang (2004) who find that training participation depends on socio-economic characteristics of non-migrant workers.

Table 3. Education, training and expenditure-based income:

Migrant workers, China 2005

\begin{tabular}{|c|c|c|c|c|c|c|}
\hline & $\begin{array}{l}(1) \\
\text { All }\end{array}$ & $\begin{array}{c}(2) \\
\text { Q10 }\end{array}$ & $\begin{array}{c}(3) \\
Q 25\end{array}$ & $\begin{array}{c}(4) \\
\text { Q50 }\end{array}$ & $\begin{array}{c}(5) \\
\text { Q75 }\end{array}$ & $\begin{array}{c}\text { (6) } \\
\text { Q90 }\end{array}$ \\
\hline Constant & $\begin{array}{l}4.846^{* * *} \\
(0.124)\end{array}$ & $\begin{array}{l}4.074 * * * \\
(0.178)\end{array}$ & $\begin{array}{l}4.537 * * * \\
(0.136)\end{array}$ & $\begin{array}{l}4.966^{* * *} \\
(0.119)\end{array}$ & $\begin{array}{l}5.005^{* * *} \\
(0.132)\end{array}$ & $\begin{array}{l}5.496 * * * \\
(0.310)\end{array}$ \\
\hline Education: Years 6-8 & $\begin{array}{l}0.121 * * * \\
(0.030)\end{array}$ & $\begin{array}{l}0.330 * * * \\
(0.108)\end{array}$ & $\begin{array}{l}0.161 * * \\
(0.076)\end{array}$ & $\begin{array}{l}0.140 * * \\
(0.065)\end{array}$ & $\begin{array}{l}0.163 * * \\
(0.072)\end{array}$ & $\begin{array}{c}0.140 \\
(0.186)\end{array}$ \\
\hline Education: Year 9+ & $\begin{array}{l}0.103 * * \\
(0.037)\end{array}$ & $\begin{array}{c}0.231 * * \\
(0.105)\end{array}$ & $\begin{array}{c}0.146^{*} \\
(0.077)\end{array}$ & $\begin{array}{c}0.128 * \\
(0.065)\end{array}$ & $\begin{array}{l}0.165^{* *} \\
(0.074)\end{array}$ & $\begin{array}{c}0.040 \\
(0.192)\end{array}$ \\
\hline Experience & $\begin{array}{l}0.381 * * * \\
(0.058)\end{array}$ & $\begin{array}{l}0.525 * * * \\
(0.123)\end{array}$ & $\begin{array}{l}0.332 * * * \\
(0.087)\end{array}$ & $\begin{array}{l}0.244 * * * \\
(0.076)\end{array}$ & $\begin{array}{l}0.387 * * * \\
(0.081)\end{array}$ & $\begin{array}{c}0.375^{*} \\
(0.215)\end{array}$ \\
\hline Experience $^{2} / 10$ & $\begin{array}{l}-0.792 * * * \\
(0.126)\end{array}$ & $\begin{array}{l}-1.109 * * * \\
(0.286)\end{array}$ & $\begin{array}{l}-0.666^{* * *} \\
(0.208)\end{array}$ & $\begin{array}{l}-0.531 * * * \\
(0.190)\end{array}$ & $\begin{array}{l}-0.876^{* * *} \\
(0.195)\end{array}$ & $\begin{array}{l}-0.746 \\
(0.510)\end{array}$ \\
\hline Experience $^{3} / 100$ & $\begin{array}{l}0.612^{* * *} \\
(0.091)\end{array}$ & $\begin{array}{l}0.870^{* * *} \\
(0.234)\end{array}$ & $\begin{array}{l}0.506^{* * *} \\
(0.174)\end{array}$ & $\begin{array}{l}0.424 * * \\
(0.164)\end{array}$ & $\begin{array}{l}0.683 * * * \\
(0.166)\end{array}$ & $\begin{array}{c}0.581 \\
(0.411)\end{array}$ \\
\hline Experience $^{4} / 100$ & $\begin{array}{l}-0.015 * * * \\
(0.002)\end{array}$ & $\begin{array}{l}-0.021 * * * \\
(0.006)\end{array}$ & $\begin{array}{l}-0.012 * * * \\
(0.004)\end{array}$ & $\begin{array}{l}-0.010 * * \\
(0.004)\end{array}$ & $\begin{array}{l}-0.016^{* * *} \\
(0.004)\end{array}$ & $\begin{array}{l}-0.014 \\
(0.010)\end{array}$ \\
\hline Manufacturing & $\begin{array}{l}-0.032 \\
(0.052)\end{array}$ & $\begin{array}{c}0.104 \\
(0.095)\end{array}$ & $\begin{array}{c}0.078 \\
(0.068)\end{array}$ & $\begin{array}{l}-0.003 \\
(0.059)\end{array}$ & $\begin{array}{l}-0.097 \\
(0.067)\end{array}$ & $\begin{array}{l}-0.243 \\
(0.165)\end{array}$ \\
\hline Services & $\begin{array}{l}-0.200 * * * \\
(0.067)\end{array}$ & $\begin{array}{l}-0.134 \\
(0.105)\end{array}$ & $\begin{array}{l}-0.196 * * \\
(0.076)\end{array}$ & $\begin{array}{l}-0.217 * * * \\
(0.066)\end{array}$ & $\begin{array}{l}-0.129 * \\
(0.075)\end{array}$ & $\begin{array}{l}-0.107 \\
(0.205)\end{array}$ \\
\hline Tenure & $\begin{array}{c}0.021 \\
(0.016)\end{array}$ & $\begin{array}{c}0.008 \\
(0.020)\end{array}$ & $\begin{array}{c}0.016 \\
(0.018)\end{array}$ & $\begin{array}{l}0.030 * * \\
(0.014)\end{array}$ & $\begin{array}{l}0.050 * * * \\
(0.015)\end{array}$ & $\begin{array}{c}0.007 \\
(0.038)\end{array}$ \\
\hline Children & $\begin{array}{l}0.216^{* *} \\
(0.077)\end{array}$ & $\begin{array}{l}0.268 * * * \\
(0.100)\end{array}$ & $\begin{array}{l}0.226^{* * *} \\
(0.070)\end{array}$ & $\begin{array}{l}0.208 * * * \\
(0.058)\end{array}$ & $\begin{array}{l}0.225^{* * *} \\
(0.065)\end{array}$ & $\begin{array}{c}0.104 \\
(0.166)\end{array}$ \\
\hline Female & $\begin{array}{l}0.206^{* * *} \\
(0.047)\end{array}$ & $\begin{array}{l}-0.077 \\
(0.102)\end{array}$ & $\begin{array}{c}0.082 \\
(0.074)\end{array}$ & $\begin{array}{l}0.213 * * * \\
(0.060)\end{array}$ & $\begin{array}{l}0.198 * * * \\
(0.065)\end{array}$ & $\begin{array}{c}0.172 \\
(0.183)\end{array}$ \\
\hline Training Time & $\begin{array}{l}0.046^{* *} \\
(0.016)\end{array}$ & $\begin{array}{l}0.054 * * * \\
(0.015)\end{array}$ & $\begin{array}{l}0.042 * * * \\
(0.011)\end{array}$ & $\begin{array}{l}0.046 * * * \\
(0.010)\end{array}$ & $\begin{array}{l}0.039 * * * \\
(0.012)\end{array}$ & $\begin{array}{c}0.040 \\
(0.032)\end{array}$ \\
\hline Observations & 382 & 382 & 382 & 382 & 382 & 382 \\
\hline $\mathrm{R}^{2}$ & 0.26 & 0.25 & 0.19 & 0.17 & 0.13 & 0.12 \\
\hline
\end{tabular}

Note: Standard errors in parentheses, $*, * *$ and $* * *$ denote $10 \%, 5 \%$ and $1 \%$ levels of significance respectively. The dependent variable is the log of the expenditurebased measure of wages, $\mathrm{LW}^{2}$.

Finally, we pay more attention to gender differences. We employ the BlinderOaxaca decomposition ${ }^{19}$ to gain an insight on the source of gender wage differences

${ }^{19}$ See Chen et al. (2005) for details. 
in migrant workers. A brief explanation of the procedure follows. Suppose that $Z_{j}$ is the vector of all explanatory variables in (2) for two groups of workers $(j=0,1)$ where $\mathrm{j}=1$ is the high income group and $\mathrm{j}=0$ is the low income group.

$$
L W_{j}=Z_{j} \beta_{j}+e_{j}, \quad E\left(e_{j}\right)=0, j \in\{0,1\}
$$

Then the mean outcome difference is

$$
\boldsymbol{D}=\overline{\boldsymbol{L}}_{1}-\overline{\boldsymbol{L} W}_{0}=\left(\boldsymbol{a}_{1}+\overline{\mathbf{Z}}_{1}^{\prime} \hat{\beta}_{1}\right)-\left(\boldsymbol{a}_{1}+\overline{\mathbf{Z}}_{0}^{\prime} \hat{\beta}_{0}\right)
$$

$\overline{\boldsymbol{L} W}$ is the sample mean of the income variable, $\overline{\boldsymbol{Z}}$ is the mean vector of regressors and $\mathbf{a}_{1}$ and $\mathbf{a}_{0}$ are the baseline predictions for the groups (i.e., constants). Then, group differences can be attributed to three components: (a) differences in observable characteristics (i.e., endowments); (b) differences in marginal effects (i.e., discrimination) and (c) differences in constants (i.e., unexplained). Hence, the group differences can be decomposed as

$$
D=\left(\bar{Z}_{44}-\bar{Z}_{4}\right)^{\prime} \hat{\beta}_{1}+\bar{Z}_{14}^{\prime}\left(\hat{\beta}_{2}-\hat{\beta}_{49}\right)+\left(a_{4} \bar{\beta}_{49}\right)
$$

Table 4 has the results of the Blinder-Oaxaca decomposition using (2) and the 'expenditure-based' income measure, $\mathrm{W}^{2}$. Columns $1-2$ use the lowest $25 \%$ of the distribution while columns 3-4 use the top $25 \%$. In the former, the total endowment effect is -0.045 and statistically significant. This says that females would have earned $4.5 \%$ less if both males and females had the same endowment. Column 1 describes the contribution of individual factors to explaining the endowment effect while column 2 summarises the contribution of specific factors to the discrimination effect. Column 1 suggests that females would have earned $1 \%, 0.7 \%, 0.4 \%$ and 1.5 more if endowments for years 6-8, years9+, tenure and children respectively were the same for both genders. On the other hand, had females received the same amount of training as males (i.e., see Table 1), wages for females would have been $0.5 \%$ lower 
than observed. At the lower panel of Table 4, there is a summary of the total endowment effect of education and experience since the effects of these two factors are not linear. These suggest that the net effect of education is $1.7 \%$ and that of experience is $-8.1 \%$; that is, female wages would have been higher and lower respectively if endowments on education and experience were equalised.

Table 4. Decomposition of gender differences in wages by quantile: Migrant workers, China 2005

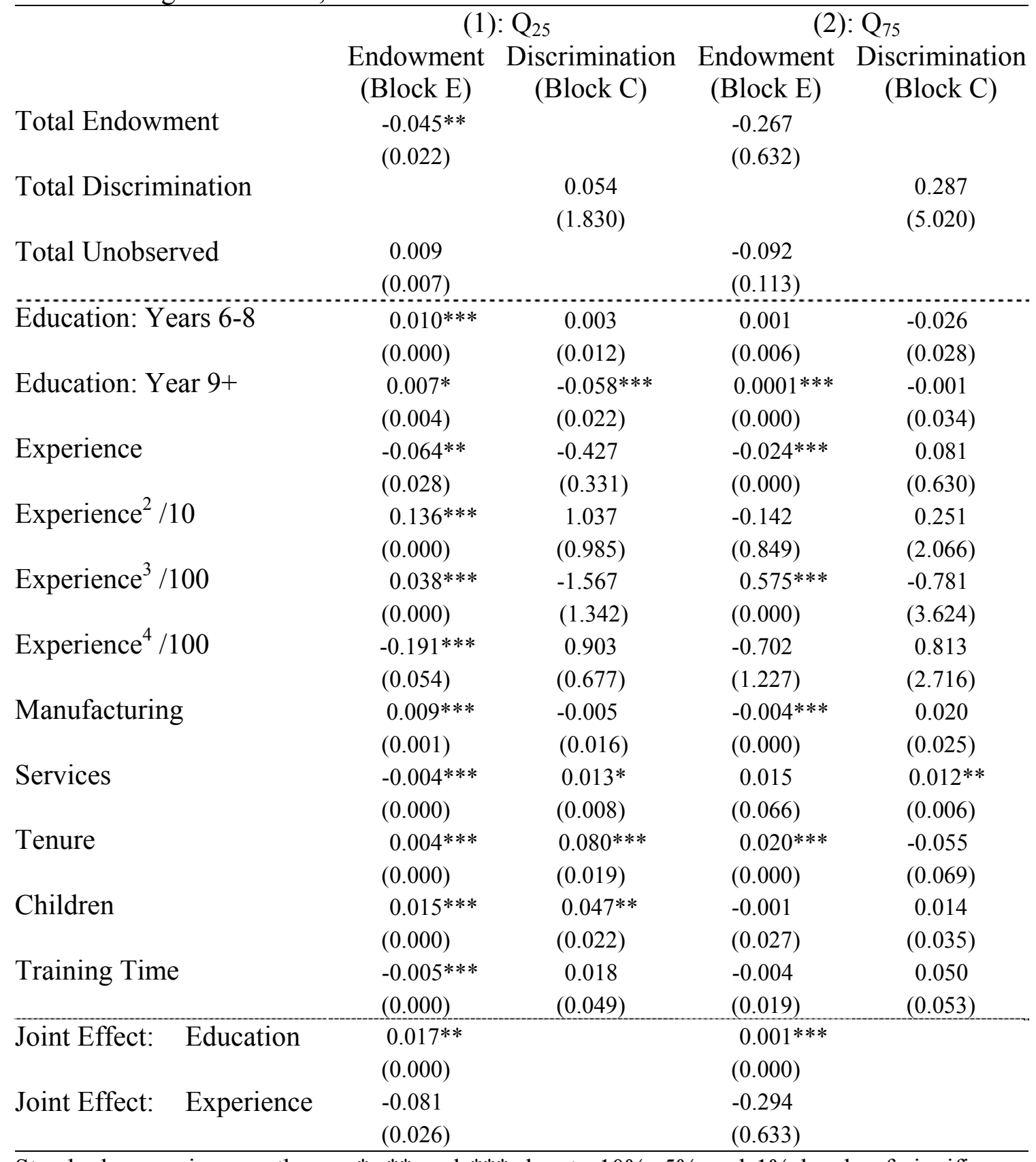

Standard errors in parentheses, $*, * *$ and $* * *$ denote $10 \%, 5 \%$ and $1 \%$ levels of significance respectively. The dependent variable is the log of the expenditure-based measure of wages, $\mathrm{LW}^{2}$. 
In contrast, the total discrimination effect is 0.054 but it is not statistically significant. Some individual factors, however, appear to contribute significantly to the discrimination effect. Thus, wages for females would have been 5.7\% lower, $8 \%$ higher and 5\% higher if there was no discrimination against them with respect to higher education (i.e., year 9+), 'tenure' and 'children' respectively.

Finally, columns 3-4 in Table report on the decomposition of wages at the top $25 \%$ of the distribution. Here, the total endowment and discrimination effects are not statistically significant. The results are somewhat similar with those in columns 1-2 but there are some important exceptions. First, the endowment effects of education and experience are much weaker, though they share the same sign. Second, wages of the more able female workers would have been $2 \%$ higher had job tenure been longer as it is the case for men. With respect to discrimination, column 4 shows that wage parity could improve $1.2 \%$ if female pay discrimination was to be eliminated in the service sector.

\section{Summary of Results}

The empirical evidence in this paper can be summarised as follows. First, we find that the 'income-based' measure of earnings, as reported by workers, seems to be contaminated by measurement errors while the 'expenditure-based' measure seems consistent with economic theory that suggests that education and work experience are key determinants of labour income. Second, the completion of lower middle school or higher education boosts wages by $12.1 \%$ and $10.3 \%$ respectively. However, the returns to education are much higher for low income workers. This suggests that education is more important than previously thought but its impact is nonlinear. Third, the returns to job training are also significant at about $4.5 \%$ and are remarkably similar across the whole different quantiles at the bottom $75 \%$ of the wage distribution.

Fourth, work experience as a migrant associated with substantial returns that, again, are higher for workers at the lower $10 \%$ of the distribution. This finding alludes 
to considerable gains in earnings and productivity if China were to encourage migrant workers and their families to stay in big cities longer. To illustrate the impact of migrant-worker experience, Figure 1 depicts the cumulative and marginal effects of work experience on earnings (in percentages) as reflected in the coefficient estimates of columns two and four in Table 3. Clearly, the returns to work experience increase sharply after 8-10 years of migrant experience while cumulative returns to experience exhibit bi-modality with the global maximum at about 15 years of experience for the lowest quantile and about 20 years for the median group. These periods contrast sharply with the sample averages of migrant experience of 4.1 and 3 years for men and women respectively (see Table 1).

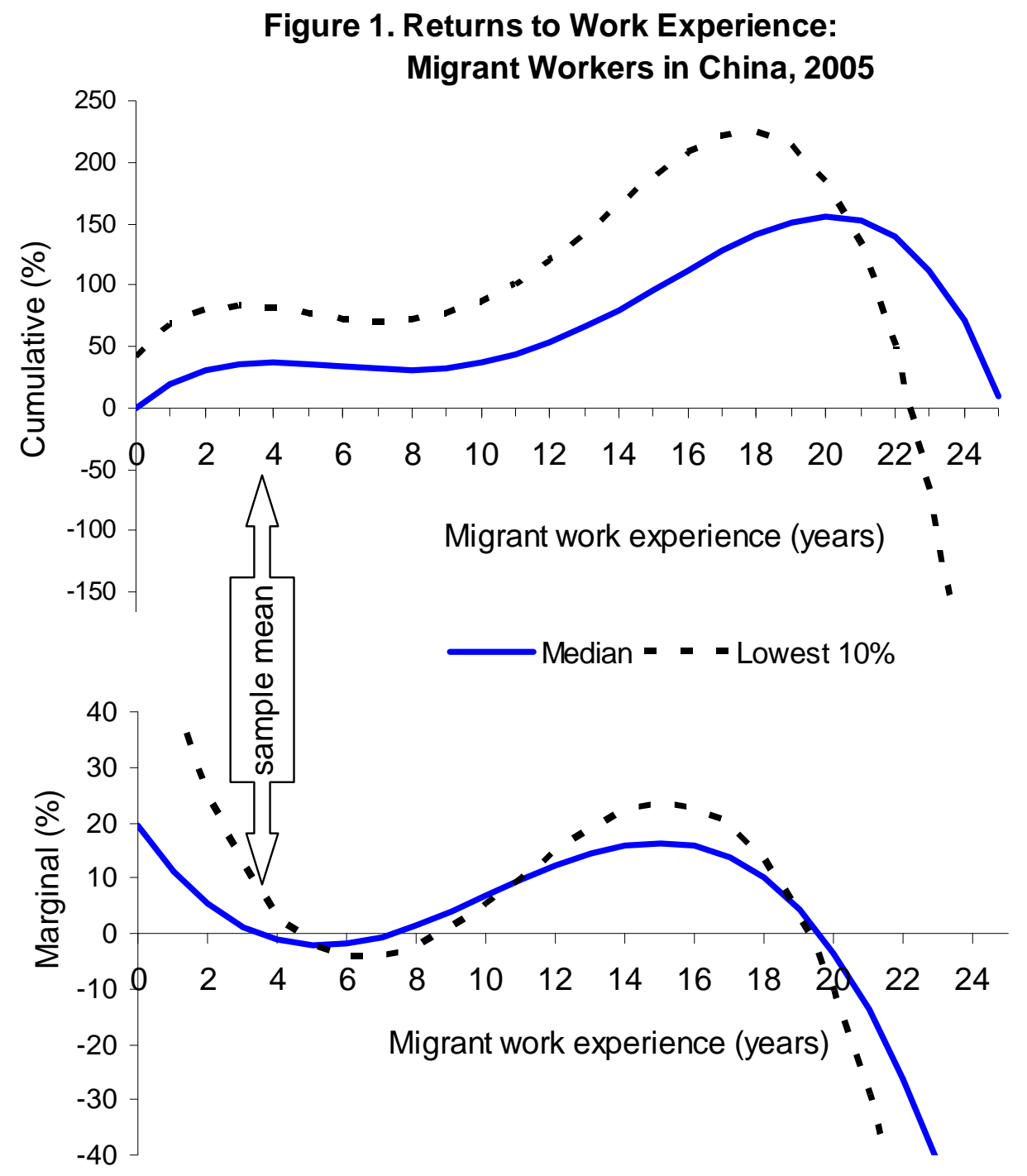

Source: Migrant Workers Survey, 


\section{Policy Implications}

The evidence presented above provides several new insights on the labour market experience of migrant workers in China. We identify three key findings that have important policy implications for China and developing nations in general. First, education matters very much but it is more valuable for the lowest income group. Second, job training for people with low education such as migrant workers raises living standards considerably. When compared to non-migrant workers and their female counterparts, it seems that living standard of male migrant workers can benefit from more adequate training at the workplace. Third, work experience in big cities contributes significantly to labour income for migrant workers and their families. ${ }^{20}$

The above findings become all too important for policy given that migrant workers are severely disadvantaged in China due to institutional distortions and the rural-urban divide in educational endowments. The former relates to the Hukou system of residence that distorts the cost structure of further education, medical care and retirement and penalises migrant workers. ${ }^{21}$ Lacking a permanent residence also means that migrant workers are largely banned from public sector jobs and professional occupations (Sun et al. 2005), and they are credit constrained by the major financial institutions (Cheng and Xu 2005).

Another source of disadvantage stems from uneven economic development and second-rate education in rural China. Migration provides an escape from credit constraints but also raises the opportunity cost of education. This makes migrant workers vulnerable to poverty traps as they are deprived of personal development and further education. This is consistent with evidence in de Brauw and Giles (2006) who find a robust inverse relationship between migration opportunities and enrolments at high school level. Similar results are observed in the Henan Province by Wan (2004).

The Chinese government has been working on a number of initiatives to remove discriminatory policies against migrant workers in China with the ultimate objective

\footnotetext{
${ }^{20} \mathrm{He}$ and Guo (2004) find that the intention for permanent migration is higher for migrant workers with higher levels of education, the young and those living in urban areas longer.

${ }^{21}$ According to Chen (2004), migrants pay their contribution towards old age pension, but they receive half of their contributions when they leave urban areas, an annual income loss of 200-300 billion RMB for migrant workers.
} 
of improving their skills and welfare. In a recent document, the State Council (China's Cabinet) has issued a directive to its departments and local governments to lift their discriminatory rules and regulations against migrant workers in China and to treat migrant and urban workers equally (The State Council 2006). As far as the education and training of migrant workers are concerned, the governments have so far focused on the exemption of school fees and other expenses for rural compulsory education for up to middle school. In 2004, the central Government initiated a nation wide premigration training program for workers who intend to migrate, the 'Sunlight Project'. The plan is expected to provide training to up to 2.5 million potential migrant workers each year from 2004-2005 and to further 20 million over the period 2006-2010, so as to encourage rural labourers to move to urban areas. The project has been implemented in the migrant source areas, including major grain producing areas, poor rural areas and old revolutionary areas of China (Sun et al, 2005, pp.161-3).

The evidence in this study sheds new light on the effect of education and training on the incomes of migrant workers in China. It shows that the returns to education and job training for migrant worker are substantial. An important policy recommendation from this study is that, in addition to the exemption of fees and other expenses for schools in rural areas, the government should also consider strengthening technical education in rural China. Currently, technical schools provide 2-3 years technical training for middle school graduates (with nine years education). Parents are, however, required to pay high fees and board expenses in order to register their children with such schools, as they are beyond the compulsory education system. The training provided at these technical schools should be of high quality and market oriented. Equipped with the training received from technical schools, more rural labour can move directly into the industries that required more skills and so as to increase their incomes and improve their job security.

Another policy recommendation is that, given the high return of job training, extra public resources should be dedicated toward on-the-job training to complement the general training provided by local government agencies in the migrant source areas. Admittedly, it is difficult to find qualified managers and teachers to provide quality training to potential migrant workers in the poor and remote counties of China, and it is also challenging for local governments in poor and remote areas to 
understand the changing demand for the skills of migrant workers. Thus, the Central Government should provide more incentives to employers in the destination areas to encourage greater participation in job training by migrant workers.

The effectiveness of worker training programs depends on the quality and the relevance of the training provided as well the motivations from the migrant workers to receive the training, and employer incentives to provide training. The new evidence here shows that, on average, a migrant worker reaches the peak of her income around 15-20 years of work experience and the returns to migrant work experience are considerable. Thus, the evidence suggests that both migrant worker and employer incentives to training ought to increase substantially if migrant workers are allowed to stay in urban areas longer, or even permanently. It follows that the removal of barriers to long-term residency in urban areas for migrant workers and their families would be a sensible policy initiative of high priority. Obviously, an improvement in the education and training system for migrant workers and the removal of the dual labour market will greatly assist China to develop more value-added industries in manufacturing and services so as to sustain China's high rate of growth.

Finally, some of the above recommendations may be useful to other developing countries that rely on domestic migrant workers. Countries such as India can only benefit from China's experience.

\section{References}

Acemoglu, D., Pischke, J. (1999). Beyond Becker: Training in Imperfect Labour Markets. The Economic Journal, 109 (453), 112-42.

Angrist, J., Chernozhukov, V. and Fernandez-Val, I. (2006). Quantile regression under misspecification, with an application to the U.S. wage structure. Econometrica, 74 (2), 539-563.

Arulampalam, W., Booth, A.L., Bryan, M.L. (2004). Training in Europe. Journal of the European Economic Association, 2 (2-3), 346-60.

Au, C., Henderson, J.V. (2006). How Migration restrictions limit agglomeration and productivity in China. Journal of Development Economics, 80 (2), 350-388. 
Baldwin, J.R., Johnson, J. (1995). Human Capital Development and Innovation: The Case of Training in Small and Medium Sized-Firms. Micro-Economic Analysis Division, Statistics Canada: Ottawa.

Buchinsky, M. (1994). Changes in the US wage structure 1963-1987: application of quantile regression. Econometrica, 62 (2): 405-458.

Card, D. (1999). The Causal Effect of Education on Earnings. in: Ashenfelter, O., Card, D., eds., Handbook of Labor Economics 3A, Elsevier Science, Amsterdam, 1801-1863.

Cardoso, A.R. (2005). Big Fish in Small Pond or Small Fish in Big Pond? An Analysis of Job Mobility. IZA Discussion Paper No. 1900.

Chen, X. (2004). Resource Allocation and Rural Development in China. Chinese Rural Economy Monthly 1, 4-9.

Chen, Y., Dimurger, S., Fournier, F. (2005). Earnings Differentials and Ownership Structure in Chinese Enterprises. Economic Development and Cultural Change 53 (4), 933-58.

Cheng, E., Xu, Z. (2005). Domestic Money Transfer Services for Migrant Workers in China. Report prepared for the Consultative Group to Assist the Poor CGAP, October.

Communist Party's School (2005). A Survey of Nine Years Compulsory Education in Rural China. in: Yang, D.P., ed., The Development Report of China's Education, Social Sciences Academic Press China, 297-305.

de Brauw, A., Giles, J. (2006). Migrant Opportunity and the Educational Attainment of Youth in Rural China. September 12, IZA Discussion Paper, No. 2326.

de Grip, A. (2004). Evaluating Human Capital Obsolescence. EC-OECD Seminar on Human Capital, Maastricht University, Brussels.

de Grip, A., van Loo, J. (2002). The Economics of Skills Obsolescence: A Review. in: de Grip, A., van Loo, J., Mayhew, K., eds., The economics of Skills Obsolescence: Theoretical innovations and empirical applications, 1-26, Research in Labor Economics 21, Elsevier Science, Amsterdam.

Du, Y., Park, A., Wang, S. (2005). Migration and Rural Poverty in China. Journal of Comparative Economics 33 (4), 688-709.

Fleicher, B.M., Wang, X. (2004). Skill differentials, return to schooling, and market segmentation in a transition economy: the case of Mainland China. Journal of Development Economics 73 (1), 315-28.

Genius, M. and Strazzera, E. (2008), Applying the copula approach to sample selection modelling. Applied Economics, 40, 1443-1455. 
Guangdong Enterprises Survey Team (2006). A Study Report on the Development of SMEs and Employment in Guangzhou City. Guangdong Bureau of Statistics, www.gzstats.gov.cn.

Hanushek, E.A., Wößmann, L. (2007). The Role of School Improvement in Economic Development. CESifo Working Paper 1911.

He, P., Guo, J. (2004). An Approach to the Rural Migrant Labours Intentions of Migration into Cities under Institutional Limitations. Chinese Rural Economy Monthly 10, 64-68.

Heckman, J. (1979). Sample selection bias as a specification error. Econometrica, 47, 153-61.

Heckman, J.J., Lochner, L.J., Todd, P.E. (2003). Fifty Years of Mincer Earnings Functions. NBER Working Paper 9732, Cambridge, MA.

Krueger, A., Lindahl, M. (2001). Education for Growth: Why and For Whom? Journal of Economic Literature 39 (4), 1101-1136.

Kuruscu, B. (2006). Training and Lifetime Income. American Economic Review 96 (3), 833 46.

Lemieux, T. (2006). The "Mincer Equation" Thirty Years After Schooling, Experience, and Earnings. in: S. Grossbard, ed. Jacob Mincer: A Pioneer of Modern Labor Economics. Springer.

Li, T., Zhang, J. (1998). Return to education under collective and household farming in China. Journal of Development Economics 56 (2), 307-35.

Linsley, I. (2005). Causes of Overeducation in the Australian Labour Market. Department of Economics, University of Melbourne, Research Paper 940.

Liu, Z., Xiao, J. (2006). The Accumulation of Human Capital over Time and Its Impact on Salary Growth in China. Education Economics 14 (2), 155-80.

Meng, X. and Gregory, B. (2007). Exploring the Impact of Interrupted Education on Earnings: The Educational Cost of the Chinese Cultural Revolution. IZA Discussion Paper No. 2548.

Mincer, J. (1962). On-the-Job Training: Costs, Returns and Implications, Part 2. Journal of Political Economy 70 (5), 50-79.

Mincer, J. (1974). Schooling, Earnings and Experience. Columbia University Press, NY.

Mincer, J. (1989). Job Training: Costs, Returns and Wage Profiles. NBER Working Paper 3208.

Mincer, J., Ofek, H. (1982). Interrupted Work Careers: Depreciation and Restoration of Human Capital. Journal of Human Resources 17 (1), 3-24.

Ministry of Agriculture China (2004). Attention to the Migrant Workers in China. Report. China Urban and Rural Financial News 24 March, 2. 
Murphy, K.M., Welch, F. (1990). Empirical Age-Earnings Profiles. Journal of Labor Economics 8 (2), 202-29.

Psacharopoulos, G., Patrinos, H. (2004). Returns to Investment in Education: A Further Update. Education Economics 12 (2), 111-24.

Ravallion, M., Chen, S. (2007). China's (uneven) Progress Against Poverty. Journal of Development Economics 82 (1), 1-42.

Sachs, J. (2005). The End of Poverty: How We Can Make it Happen in Our Lifetime. Penguin, London.

Sun, X., Liu, X., Liu, X. (2005). Rural Labour's Non Agricultural Employment in China. China Agricultural Press, Beijing.

Sun, Z. (2004). A Study on the Impacts of Inter-provincial Migration on Regional Economic Development. Chinese Rural Economy Monthly 3, 28-33.

The Research Group on Chinas Farmer Turn Workers (2006). Reporting on the Problems of Chinese Farmer-turned Workers. Reform [Gai Ge] 5.

The State Council (2006). A Number of Suggestions from the State Council to Tackle the Problems with Migrant Workers. State Council Document 5, www.nmpx.gov.cn.

Tong, C. (2006). The Analysis on Unequal Treatment to the Chinese Farmers During the Society Reforming. Social Sciences Academic Press, China.

Trivedi, P. K. and Zimmer, D. M. (2005). Copula modeling: an introduction for practitioners. Foundations and Trends in Econometrics, 1, (1), 1-111.

Trostel, P.A. (2005). Nonlinearity in the Return to Education. Journal of Applied Economics 8 (1), 191-202.

Tsang, M. (1996). Financial Reform of Basic Education in China. Economics of Education Review 15 (4), 423-44.

van Smoorenburg, M.S., van der Velden, R.K. (2000). The Training of School-Leavers: Complementarity of Substitution? Economics of Education Review 19 (2), 207-17.

Vella, F. (1998). Estimating models with sample selection bias: a survey. The Journal of Human Resources, 33, 127-169.

Veum, J.R. (1999). Training, Wages and the Human Capital Model. Southern Economic Journal 65 (3), 526-38.

Wan, B. (2004). A Strategic Measure for Realizing the Overall Xiaokang Society in Rural China - A finding Report on Transfer of Rural labour Forces in Henan Province. Chinese Rural Economy 1, 24-7.

Whalley, J., Zhang, S. (2004). Inequality Change in China and Hukou Labour Mobility Restrictions. NBER Working Paper 10683. 
Wößmann, L. (2003). Specifying Human Capital. Journal of Economic Surveys 17 (3), 23970.

Wu, G. (2001). Poverty Reduction Model Research - a study on labour out-migration in China. China Economic Press.

Xiao, J., Tsang, M.C. (2004). Determinants of Participation and Non-participation in JobRelated Education and Training in Shenzhen, China. Human Resource Development Quarterly 15 (4), 389-420.

Yang, D.T. (2004). Education and Allocative Efficiency: household income growth during rural reforms in China. Journal of Development Economics 74 (1), 137-62.

Zeng, X. (2004). A Study on the Effects of Human Capital in Informal Labour Market with Rural Migrant Workers in Chengdu City, Sichuan Province as An Example. Chinese Rural Economy Monthly 3, 34-38.

Zhang, X., Si, X. (2006). Education, Experience and Incomes of Migrant Workers. World Economic Papers 1.

Zhang, H., Ouyan, H., Jiang, W. (2004). Developing Migration of Rural Labour Forces as a Strategic Industry - A finding Report from Sichuan and Guizhou Provinces. Chinese Rural Economy Monthly 1, 28-33.

Zheng, L. (2004). On the Comparative Advantage of Chinese Industries. Chinese Economy 37 (2), 6-15. 